\title{
The Uses of Early Tibetan Printing: Evidence from the Turfan Oasis
}

\author{
Sam van Schaik
}

Little is known about the origin and early development of printing in the Tibetan script, but archaeological evidence points to the region to the north of Tibet, around the Tarim basin and the Gobi desert. This area, nowadays often called Chinese Central Asia or Eastern Central Asia was the site of the early trade routes popularly known as the Silk Road, a multicultural and multilingual region in which Tibetan culture participated from the 7 th century onwards. Here I will look at one of the major Silk Road archaeological sites, the Turfan oasis, and what we can learn about the early development of Tibetan printing from the artefacts found there. I will argue that the variety of printed and stamped material discovered in Turfan show alert us to the fact that from the beginning Tibetan printing served a variety of social and ritual functions, wider than the production and circulation of books.

Woodblock printing was already being practised in China by the mid-seventh century, when Xuanzang organized the printing of a million copies of the figure and dhärañ of the bodhisattva Samantabhadra. Material evidence from the same period was found at Turfan in 1974: a print of a Sanskrit dhârañi which has been dated to between $65^{\circ}$ and 670 . Also discovered in Turfan by the Otani expedition was a scroll containing part of the Saddharmapundarikā sütra dating from the end of the seventh century. ${ }^{1}$ The earliest dated and complete printed book is of course the Vajracchedikā sūtra (Or.8210/P.2) dated to 868, taken by Aurel Stein from the library cave at Dunhuang, which has an ornately carved image the Buddha teaching reproduced on the first panel.

When we turn to printed material in Tibetan, the earliest dates are much later than these. A single sheet found in the Dunhuang collections is a print or stamp in the Tibetan script, used to transcribe a dhāraṇı text from Sanskrit,

1 A good summary of the earliest dated printed books discovered in East Asia can be found in Pan 1997, unfortunately in the context of a polemical debate about whether printing originated in China or Korea. See also Drege 1984 and Konicki 2012.

(C) SAM VAN SCHAIK, 2016 | DOI 10.1163/9789004316256_011

This is an open access chapter distributed under the terms of the Creative Commons Attribution-

Noncommercial 3.0 Unported (CC-BY-NC 3.0) License. 
via Chinese. ${ }^{2}$ Apart from this single case, probably dating from the tenth century, the earliest known printed books and fragments are those found at the site of Kharakhoto, which flourished under the Tangut kingdom. We know from Tibetan historical sources that Tibetans were influential at the Tangut court from the middle of the twelfth century until the conquest of the Tanguts by Genghis Khan's Mongol army in 1223. The only printed booklet from Kharakhoto that has been studied in any detail is Xт 67 from the Institute of Oriental Manuscripts in St Petersburg. It contains colophon information dating it to the late twelfth century. ${ }^{3}$

Thus, based on the present state of our knowledge, it seems that printing in the Tibetan script began in Eastern Central Asia among the Tanguts, before being adopted by the Mongol empire. The activities of printing in Tibetan among the Mongols moved to the capital of the Yuan dynasty, Dadu, near Beijing, often sponsored by queens at the Mongol court. Printed books from the Mongol period were known in Tibet as Hor par ma, 'Mongolian prints' and share certain features, including Chinese page numbers, which were probably added for the convenience of the Chinese printers. Several of these Mongolian prints have been identified in the collections of Tibetan monastic libraries (Sangpo 2013). According to Tibetan literary sources, printing continued in Eastern Central Asia: a commentary on the Hevajra tantra was printed in Gansu province in 1273, and there are references to the printing of books in eastern Tibet as early as the beginning of the 13th century, though there is currently no extant physical evidence of this activity. ${ }^{4}$

In this paper I will be looking at evidence of printing in Eastern Central Asia from the Mongol period (and perhaps a little earlier) found in the Turfan oasis. As we will see, this material is different from the Hor par ma found in Chinese and Tibetan collections, in that we have no complete books, only isolated pages, scraps, and small printed or stamped slips of paper. Yet this may not be a disadvantage. While manuscript and printed material recovered from archaeological sites like those of the Turfan oasis are generally in far worse condition than those kept in libraries, and only rarely complete, they result

2 This manuscript, Pelliot tibétain 4216, was brought to my attention by Matthew Kapstein (November 2015). There seems to have been some attempt to partly Sanskritize the Tibetan letters in this print: the $-i$ vowel often extends all the way behind the letter form, in imitation of the long - $\bar{\iota}$ vowel in Sanskrit as written in the Siddhamatrka style.

3 See Stoddard 2010 and Shen 2010. It would be wrong to assume that all of the archaeological finds at Kharakhoto predate this conquest; indeed, some of the manuscripts contain texts that seem to have been translated in the Mongol period, and a terminus ad quem of the late fourteenth century is now accepted (Samosyuk 1999: 45)

4 van der Kuijp 2010, 453-455. 


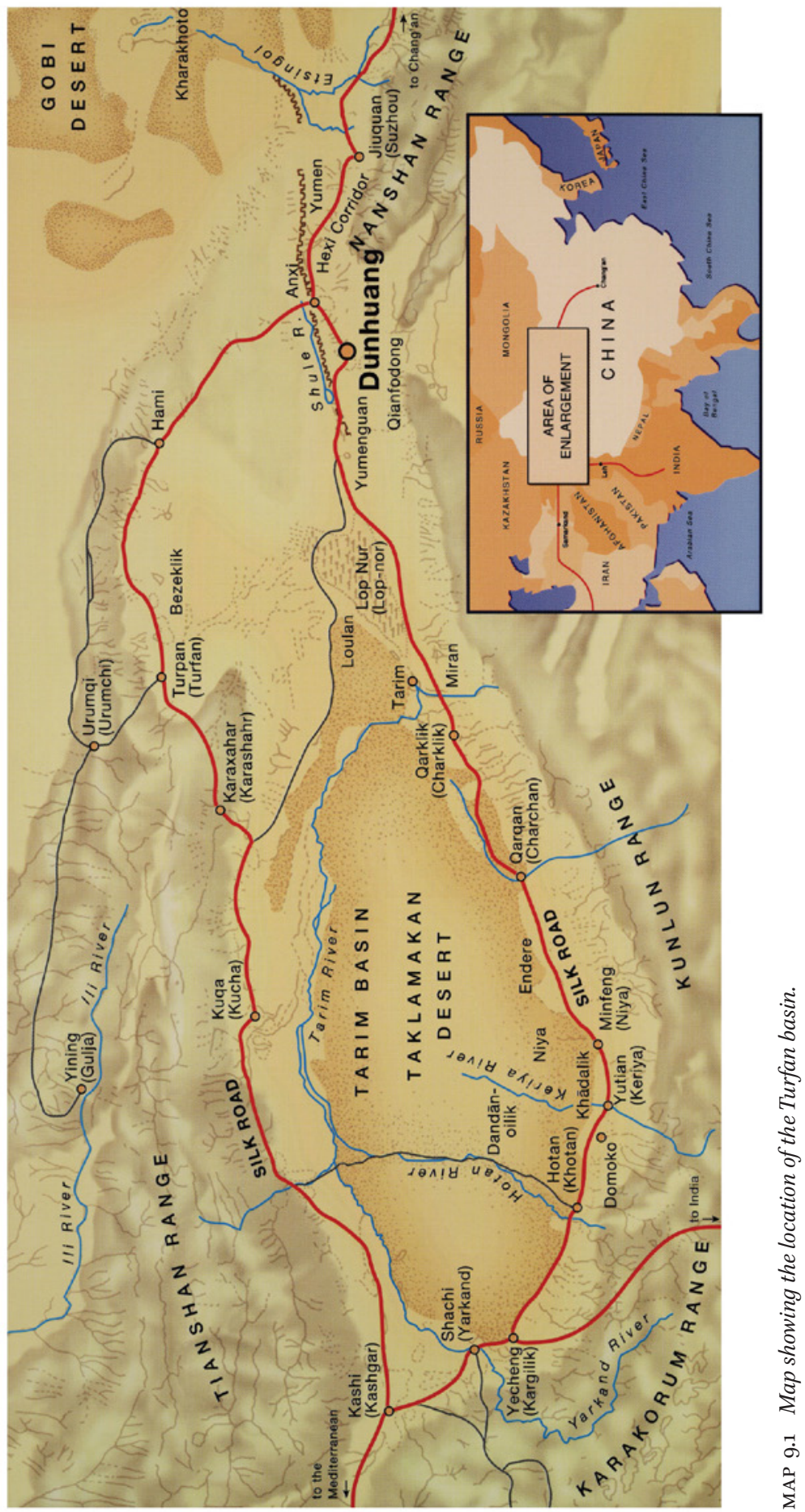


from, and represent, a greater variety of social practices than a library collection does. ${ }^{5}$ My aim in this paper then, is to introduce the Tibetan printed material from the Turfan oasis, and to take advantage of the miscellaneous nature of this material to say something about the social role of printed matter in the early stages of Tibetan print culture.

This brings us to the Turfan oasis. The oasis is a depression to the northeast of the Taklamakan desert, its deepest point being 154 meters below sea level. The main archaeological sites of Turfan are the cave temple sites of Bezeklik and Shorchuk, the cities of Kocho and Yarkhoto, and the grave site of Astana. Before the eighth century, the oasis was ruled by a succession of local dynasties, and intermittently fell under the sway of Chinese kingdoms, particularly during the Han and early Tang dynasties. In the middle of the eighth century Turfan was conquered by the Tibetan army, and was ruled by the Tibetan empire until it came under the control of Uighur Turks in the middle of the ninth century.

The Uighur kingdom in Turfan was formed from the refugees of the collapsed Uighur empire, who styled themselves Idiqut, and are known to historians as the West Uighur Kingdom. The centre of their kingdom was the city of Kocho, which they called Idiqut-schari, and their influence extended beyond Turfan to other sites of northern Taklamakan, including Kucha. The West Uighurs became vassals of the Khara-Khitan Khanate in the 12th century, and submitted to Genghis Khan in 1209. They became part of Kubilai Khan's empire, but were ruled by the Chagatai Khanate from $1275^{-1318}$. Kocho is thought to have been finally abandoned in the late 14 th century. ${ }^{6}$

The exploration and excavation of the sites of the Turfan oasis was mainly carried out by German scholars from the Museum für Völkerkunde Berlin, who had been alerted to the presence of ancient ruins in the area by travellers including the German botanist Johann Albert Regel. In the years between 1902 and 1914, four expeditions, led by Albert Grünwedel or Albert von le Coq excavated sites to the north of the Taklamakan desert; the importance of the Turfan sites led to these expeditions being known as the 'Turfan expeditions' and the collections of manuscripts, printed books and artefacts resulting from them as the 'Turfan collections'. The manuscript and print collections are now the

5 This point has been made regarding European printing by Peter Stallybrass (2007, 322): "The deluxe volumes, surviving in substantial numbers, dominate accounts of the history of printing, while the majority of broadsides, almanacs, pamphlets, and schoolbooks have disappeared completely."

6 On the Uighur kingdoms of Silk Route, see Moriyasu 2000 and Russell-Smith 2005. 
responsibility of the Berlin-Brandenburgische Akademie der Wissenschaften. The Turfan collections contain an astonishing linguistic range, including Buddhist Sanskrit and Prakrit; languages from the Silk Route cultures such as Tocharian A and B, Khotanese, Tumshuqese, Tangut and Mongolian; languages from further west including Middle Persian, Sogdian, Bactrian, Syriac, Greek and Hebrew; Chinese and Tibetan.

The Tibetan manuscripts and prints from Turfan were catalogued by Manfred Taube, and published in 1980 in his Die Tibetica der Berliner Turfansammlung which contains details of 114 items, some comprised of several fragments. This catalogue and colour images of the collections are now available on the website of the International Dunhuang Project (idp.bl.uk). The manuscripts and prints were mainly found in the sites of Qocho, Yarkhoto and Bezeklik, though the marking was not done consistently, and in many cases it is difficult to know exactly where an item was found. Most of the manuscripts, and all of the printed material is Buddhist; among the manuscripts there are also a few letters. Little work has been done on the Tibetan material from Turfan since Taube's catalogue; therefore before looking at the printed material, I will briefly review the whole Tibetan collection.

The 114 entries in Taube's catalogue comprise 111 for handwritten items and only 13 for printed or stamped items, and though a single entry sometimes covers more than one physical object, this gives an idea of the proportion of manuscripts to printed matter in the collection. All of the material is very fragmentary, with only portions of single pages surviving of what were once substantial books. Letters are written on single folded sheets, as we see in Dunhuang and later in Tibet, while Buddhist texts are written on pothi-style pages, and in a few cases in concertina or codex format books.

Because the area was populated for such a long period, it is difficult to assign dates to the Turfan material as a whole. The Uighur manuscripts from Turfan are generally dated from the 9 th to 14th centuries, with a distinction between those from the period of the West Uighur Kingdom (9th to 12th centuries) and those from the period of Mongol rule (13th to 14th centuries). It is thought that the Uighur printed material probably dates from the Mongol period. ${ }^{7}$ Some of the Tibetan material may date from earlier than this, as the Tibetans were in Qocho before the Uighurs, but the end-date of the late 14th century is probably the same, as there is no evidence of activity in Qocho and most other sites after that point. We may be able to use palaeography to gain a better idea of the dates of the Tibetan manuscripts, and by extension of the use of Tibetan in the region in general. Below I offer a brief typology of the Turfan Tibetan manuscripts, with suggested dates.

7 Personal communication, September 2013, from Simone-Christiane Raschmann. 


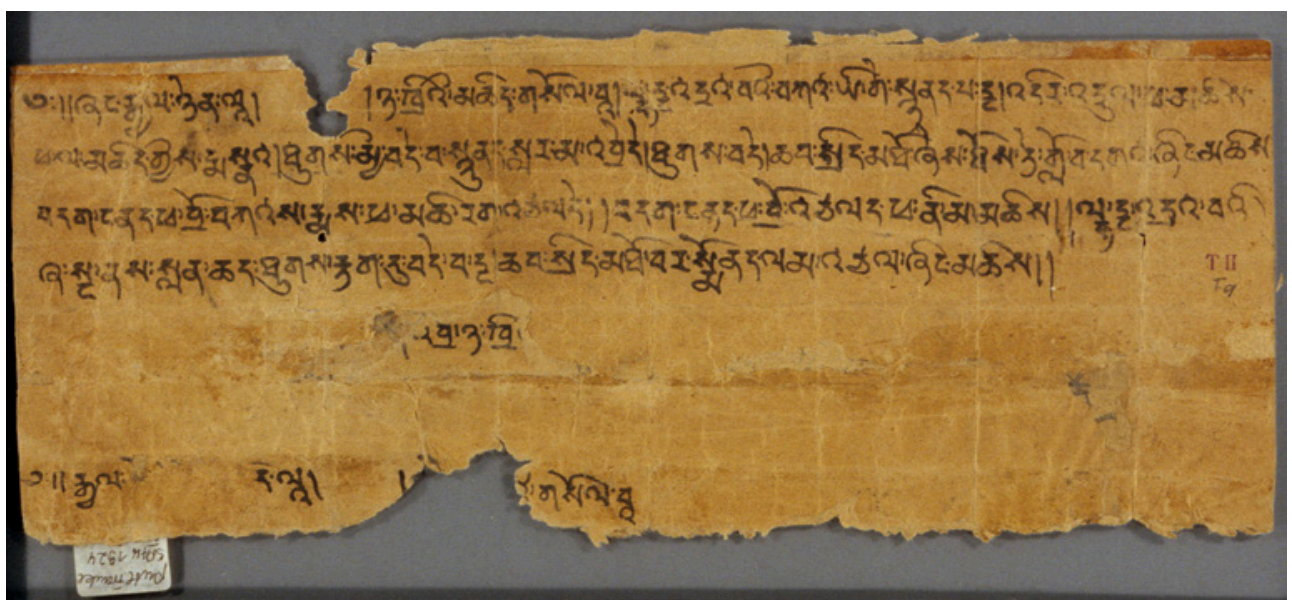

FIGURE 9.1 A Tibetan letter (TibHT 2).

(C) DEPOSITUM DER BERLIN-BRANDENBURGISCHEN AKADEMIE DER WISSENSCHAFTEN IN DER STAATSBIBLIOTHEK ZU BERLIN - PREUSSISCHER KULTURBESITZ, ORIENTABTEILUNG.

\section{Tibetan Manuscripts from Turfan}

\subsection{Letters from the 9 th Century}

It is only among the non-Buddhist manuscripts that we find writing styles comparable with manuscripts written elsewhere in Eastern Central Asia during the Tibetan imperial period. Where the manuscripts are complete enough to tell, these are letters. Several seem to be copies rather than originals, as they have been written on the blank verso of a portion of a scroll containing a Chinese sūtra. In palaeographical terms, some fall into the general categories that I have elsewhere called the 'square' and 'official' styles of Tibetan writing during the imperial period. ${ }^{8}$ Others are similar to the rough military handwriting seen in the documents found in the imperial Tibetan forts of Miran and Mazar Tagh. ${ }^{9}$ Some of the letters also make use of archaic orthography including the subfixed 'a rten and the da drag, and use the double or mid-line tsheg.

8 See van Schaik 2013. TibHT 2 is in the square style. TibHT 1, 4, 7 and 9 may be classified with documents from Dunhuang in the official style. One letter (TibHT 3 ) has palaeographic features associated with the post-imperial period, including longer descenders.

9 The Miran and Mazar Tagh documents are classified under the sequence Or.1500o/ and can be viewed on the ID P website. See also Takeuchi 1997-8. TibHT 5, 6, 10, 11, 12 are comparable to the Miran and Mazar Tagh documents. 


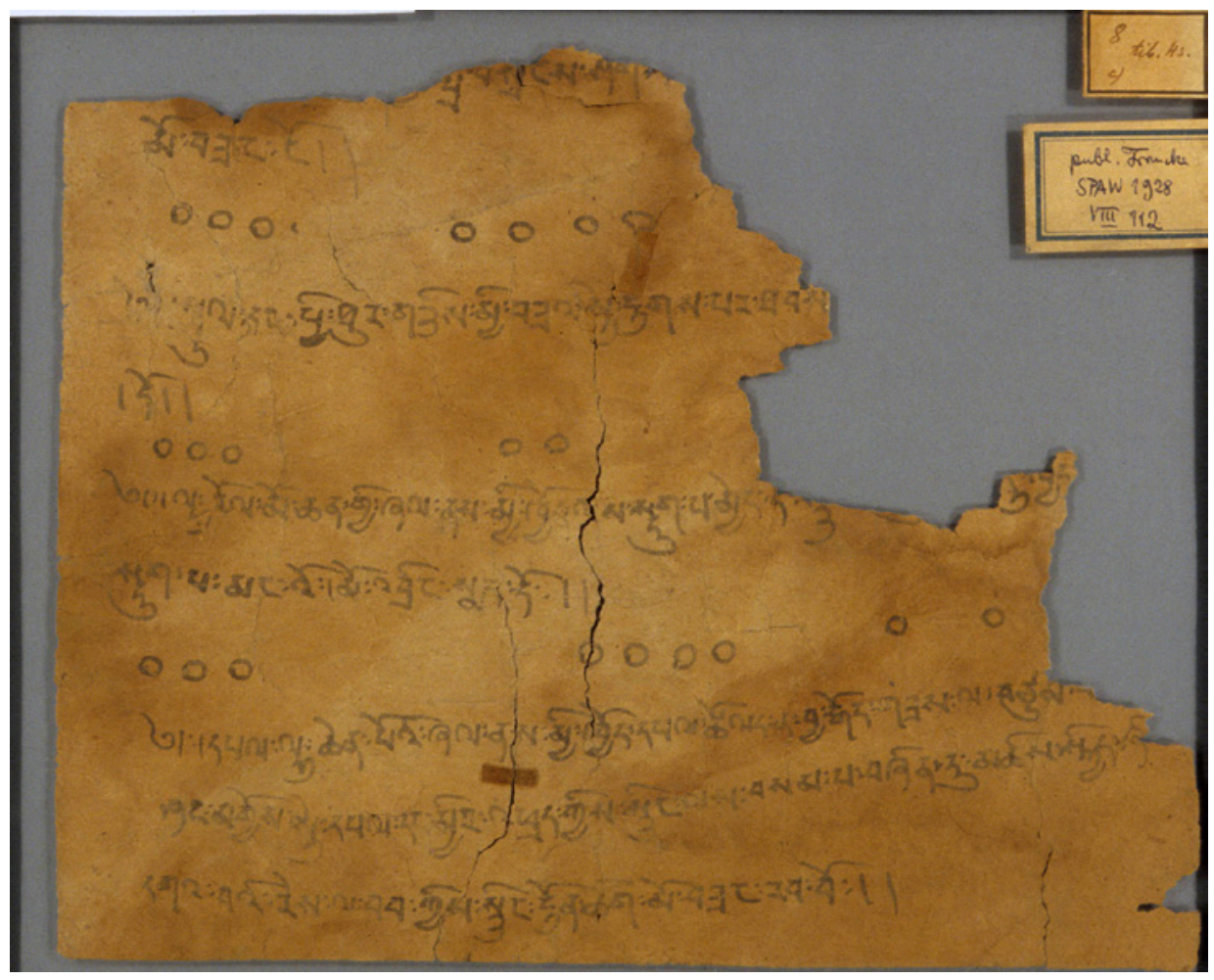

FIGURE 9.2 Fragment of a scroll (TibHT 31).

(C) DEPOSITUM DER BERLIN-BRANDENBURGISCHEN AKADEMIE DER WISSENSCHAFTEN IN DER STAATSBIBLIOTHEK ZU BERLIN - PREUSSISCHER KULTURBESITZ, ORIENTABTEILUNG.

Some of these letters addressed to people with titles that suggest the Tibetan empire, such as Zhang rgyal nyen la' (TibHT 2) and Nang rje po stag gzigs (TibHT 4). However, some of these letters (TibHT 2, 3 and 4) also contain a formalized greeting that includes an enquiry about whether the addressed person is ill (snyun), which Tsuguhito Takeuchi has suggested is characteristic of letters written after the Tibetan imperial period. As Takeuchi has pointed out, the Tibetan language and script continued to be used as a lingua franca in Central Asia after the collapse of the Tibetan empire. ${ }^{10}$ Due to this and the lack of clear references in the letters to imperial institutions, we cannot confidently assign these documents to the Tibetan imperial era, despite their palaeographical features being suggestive of that period. Therefore they should be dated between the middle and the end of the gth century.

Takeuchi 1990 and 2004. 


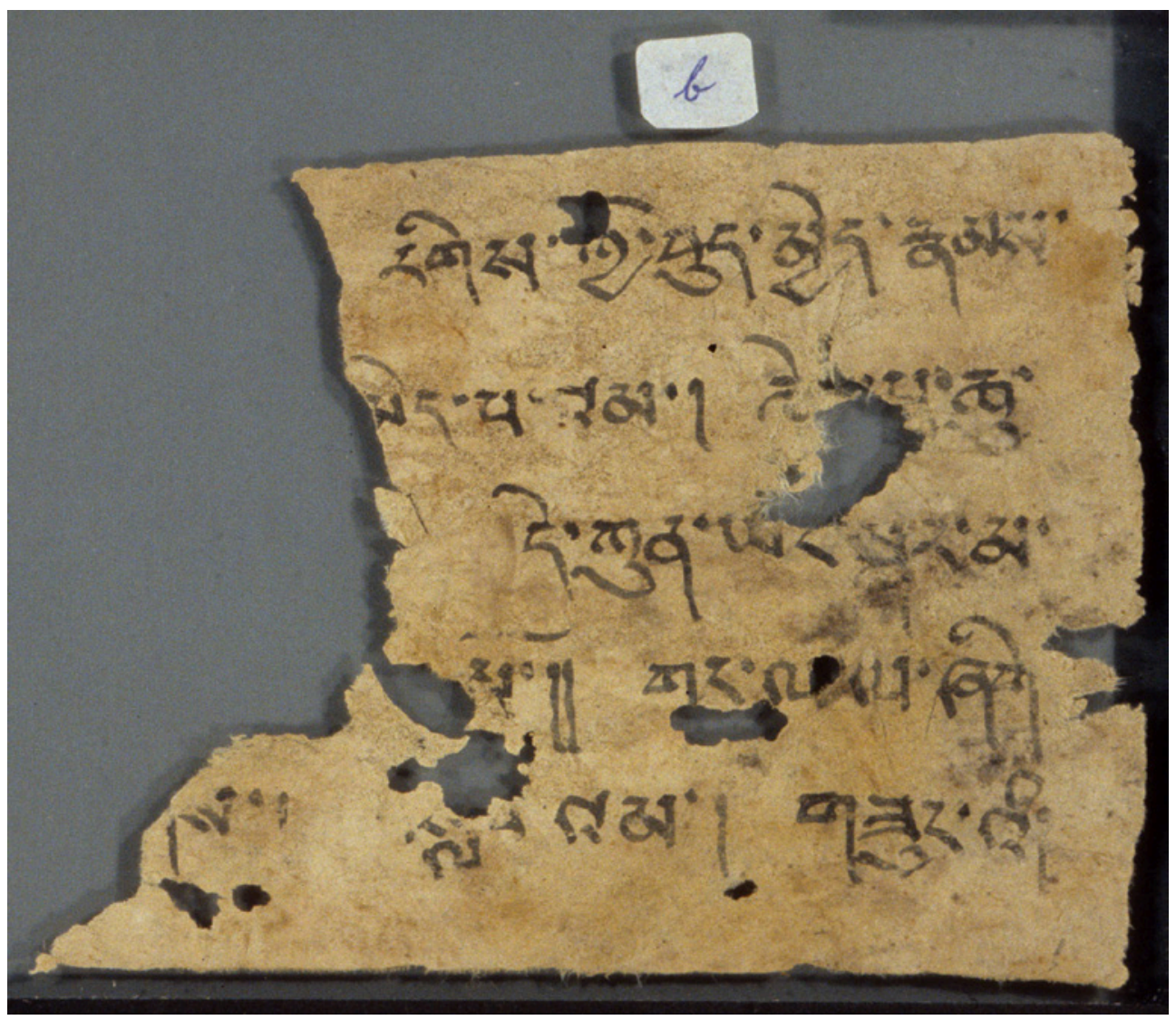

FIGURE 9.3 A Buddhist manuscript (TibHT 63).

(C) DEPOSITUM DER BERLIN-BRANDENBURGISCHEN AKADEMIE DER WISSENSCHAFTEN IN DER STAATSBIBLIOTHEK ZU BERLIN - PREUSSISCHER KULTURBESITZ, ORIENTABTEILUNG.

\subsection{Manuscripts from the gth and 1oth Centuries}

The Turfan collections include four fragments of divination texts (TibHT 31-34), with patterns of circles indicating that these are readings for dice divination. The results are spoken by various indigenous Tibetan deities. The writing is in a rough version of the square style, generally seen in documents from, or associated with the Tibetan imperial period. A similar text is found in the Dunhuang scroll IOL Tib J 740, where it is paired with a legal text; Brandon Dotson (2007) has suggested that the divination text (and others like it) were used to settle legal disputes, which would explain why this text would be circulated to far flung regions of the Tibetan empire. Several of the Buddhist manuscripts found in Turfan are also visually similar to the Tibetan 
Dunhuang manuscripts. Some of the more complete pages (TibHT 88, 89) are from a copy of the Mahābālà sütra (D.757). The somewhat rounded headed ( dbu can) letters with 'blobby' heads are characteristic of a group of 1oth century Buddhist manuscripts from Dunhuang (e.g. IOL Tib J 492).

\subsection{Manuscripts from the 11th to 14th Centuries}

It is difficult to assign a more specific date than this to the remainder of the manuscripts. Several manuscript fragments containing Buddhist texts are written in a headed style that appears to be a further evolution of the 1oth century Buddhist manuscripts. These are written making full use of a flat-nibbed pen to create shaded and angular letter forms (e.g. TibHT 63, 75-79) that are not found in the Dunhuang manuscripts. They do continue to use old orthography, including the tick on the 'a chung and the subfixed ya on ma. They are probably from the 11th or 12th centuries. Later styles are also seen in the Buddhist manuscripts written in headless (dbu med) styles. For example, TibHT 36 and 104 (both on tantric empowerment, possibly being two pages from a single original manuscript) are written in a style seen in manuscripts from the 12th and 13th centuries, and have scribal contractions and Arabic numerals, not seen in earlier manuscripts. Although TibHT 71 contains a Buddhist text (a tantric text beginning with a homage to Viravajra), it has the striking long descenders seen in official documents from the period of Mongol rule over Tibet, and probably dates to the late $13^{\text {th }}$ or $14^{\text {th }}$ century.

\section{Tibetan Printed and Stamped Material from Turfan}

The Tibetan manuscript material from Turfan, despite what is a relatively small group, compared with the manuscript finds from Dunhuang and Kharakhoto, covers a range of dates from the 9 th century through to the 14 th. This is roughly contemporaneous with the period of Uighur influence that followed Tibetan imperial rule over the area, though some of the Tibetan letters perhaps date from the imperial period. In theory, the Tibetan printed material could come from the same long period as the manuscripts, but in fact it is unlikely to date from much before the 12th century. A clue to the earliest appearance of Tibetan printed material is found in the ruined city of Kharakhoto, part of the Tangut kingdom in the 11th to 13th centuries. One of the printed books from Kharakhoto in codex form (xT 67), has a colophon suggesting that the book was produced in the Tangut kingdom in the latter part of the 12 th century. ${ }^{11}$ Given the close links between the Tangut kingdom and the West Uighur kingdom of 


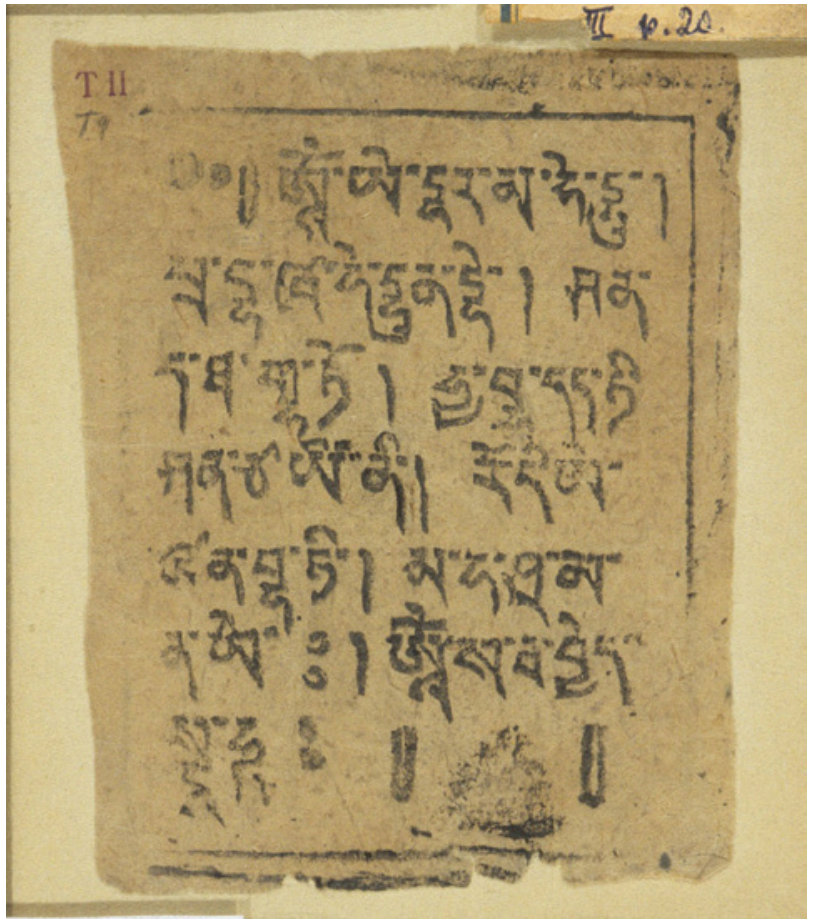

FIGURE 9.4 A prayer sheet (TibHT 49).

(C) DEPOSITUM DER BERLIN-BRANDENBURGISCHEN AKADEMIE DER WISSENSCHAFTEN IN DER STAATSBIBLIOTHEK ZU BERLIN - PREUSSISCHER KULTURBESITZ, ORIENTABTEILUNG.

Turfan, it would not be unlikely that some of the Turfan printed and stamped material also goes back as far as the 12th century.

\subsection{Paper Sheets with the ye dharma Formula}

The Berlin collections contain eleven sheets of roughly $8 \times 10 \mathrm{~cm}$, stamped with the Sanskrit ye dharma formulae in Tibetan transliteration, which were found in Kocho and the Toyuk caves, TibHT 49, 50, 51(a)-(i). The Tibetan letters in these sheets are similar to those in the Kharakhoto manuscript XT 67. The shape of the $w a$ is unusual, neither that of the gth/1oth century manuscripts, nor the established later form. At the bottom left of the stamp there is a pictorial element that is not clear in any of the extant copies; it might be a depiction of the three jewels, or a lotus flower. Other explorers in Turfan gathered more of these sheets stamped with the ye dharma formula. Aurel Stein found two, and further 54 sheets were collected by the Otani expeditions in Turfan and 


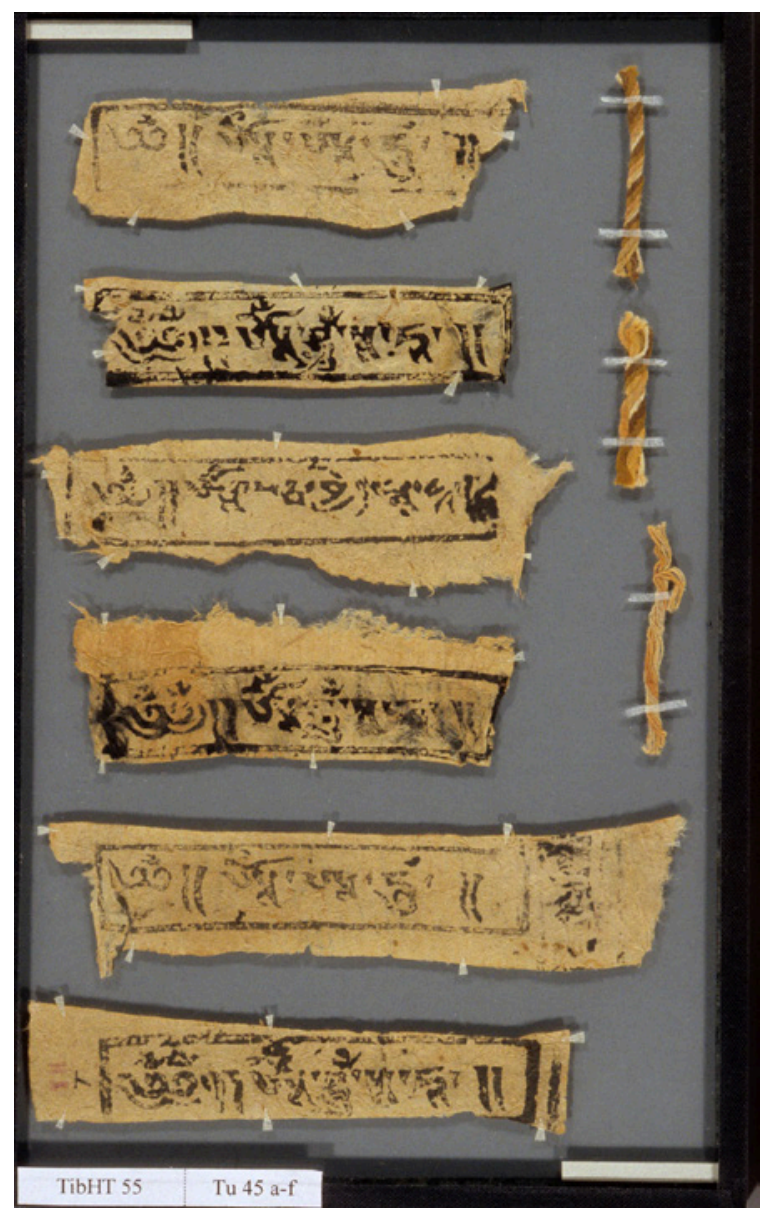

FIGURE 9.5 Mantra slips (TibHT 55).

(C) DEPOSITUM DER BERLIN-BRANDENBURGISCHEN AKADEMIE DER WISSENSCHAFTEN IN DER STAATSBIBLIOTHEK ZU BERLIN - PREUSSISCHER KULTURBESITZ, ORIENTABTEILUNG.

are now held in the Ryūkoku University. Through Carbon-14 dating, one of the Otani sheets has been dated between 880 and $1140 .^{12}$

The size of the ye dharma sheets, and the unevenness of the inking make it likely that these were created by stamping rather than printing, i.e. the wooden block was pressed down on the sheet, rather than the sheet being laid across

12 Takeuchi 1990, 210. The two Stein items are Or.1500o/546 \& Or.8212/1387, and have the site mark H.B., denoting the site Kichik-Hasser, which is in Turfan. 
the block. Stamped prayers in Sanskrit are found among the Dunhuang manuscripts; the sheet IOL San 1446 contains five stamped prayers or dhäranīs and three images of deities. It is possible that Tibetan stamped paper like the Turfan ye dharma sheets developed from an existing tradition of stamping Sanskrit mantras, and that these predate the development of printing in the Tibetan language.

\subsection{Paper Slips Stamped with Mantras}

The Turfan collections contain another form of stamped paper, even smaller than the ye dharma prayer sheets: ten paper slips around $3 \mathrm{~cm}$ high and $7-10 \mathrm{~cm}$ long, collected under the two pressmarks TibHT 55 and 56 . The mantras include ōm à hüm, ōm hüm svāhā and ōm sarvavid svāhā (the latter being the mantra of Sarvavid Vairocana, the central deity of the Sarvadurgatipariśodhana tantra). The slips are housed alongside pieces of multicoloured string, though the relationship between slips and string is unclear. It is likely that the slips were originally intended to be inserted inside statues; bundles of them may have been tied together with string for this purpose. Handwritten mantra slips were also found in Turfan (TibHT 58 ); these probably served the same purpose as the stamped slips, which would be an example of the simultaneous use of two technologies to serve the same function. The ye dharma sheets discussed above may have had a similar consecrational function, or have been used as votive offerings.

\subsection{Paper Sheet with Image of Tārā and the Phyag 'tshal nyer gcig in Three Languages}

The two fragments, TibHT $107(\mathrm{a})$ and (b) come from a single original sheet, with the image of a deity in the top portion, and a text below in three languages: Sanskrit, Tibetan and Uighur/Mongolian. The text on these fragments can be identified as the Phyag 'tshal nyer gcig, 'Praise to the 21 Tārās' and the image of the deity is almost certainly one of the 21 forms of Tārā. Given that each verse of this prayer applies to one of the 21 forms, this sheet may have been one of a set. The Sanskrit is written in the ornate form known in Tibet as lan tsha, which probably derives from an 11th-12th century Nepalese formal style. ${ }^{13}$ The Tibetan letters are better formed than in the stamps discussed above. Below the Tibetan is a fragment of Uighur script, too little to determine whether the text is in Uighur or Mongolian.

This prayer sheet is a direct descendent of similar printed sheets in Chinese, dating from the 9th century onwards; see for example Or.8210/P.14. Other early printed (or perhaps stamped) sheets were found in Kharakhoto, with circular

13 On this script and its relation to the Tibetan script, see van Schaik 2011. 


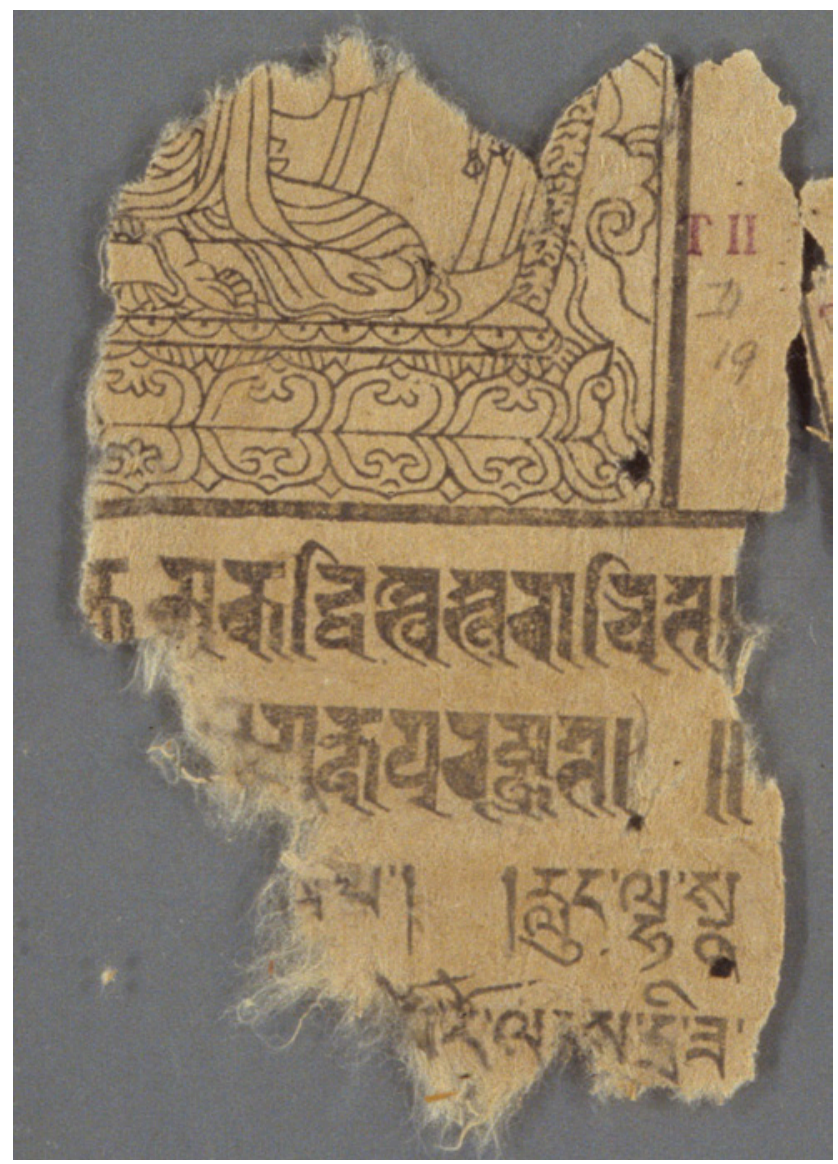

FIGURE 9.6 Sheet with image and prayer (TibHT 107).

(c) DEPOSITUM DER BERLIN-BRANDENBURGISCHEN AKADEMIE DER WISSENSCHAFTEN IN DER STAATSBIBLIOTHEK ZU BERLIN - PREUSSISCHER KULTURBESITZ, ORIENTABTEILUNG.

diagrams containing Tibetan prayers and dhäraṇī. ${ }^{14}$ In the other direction, these early printed sheets can be linked to the rlung rta (prayer flags) and other forms of printed combinations of images and prayers common in Tibetan religious practice through to the present day.

14 These are Xт 16b and Xт 23; both are reproduced and discussed in Piotrovsky 1993. 


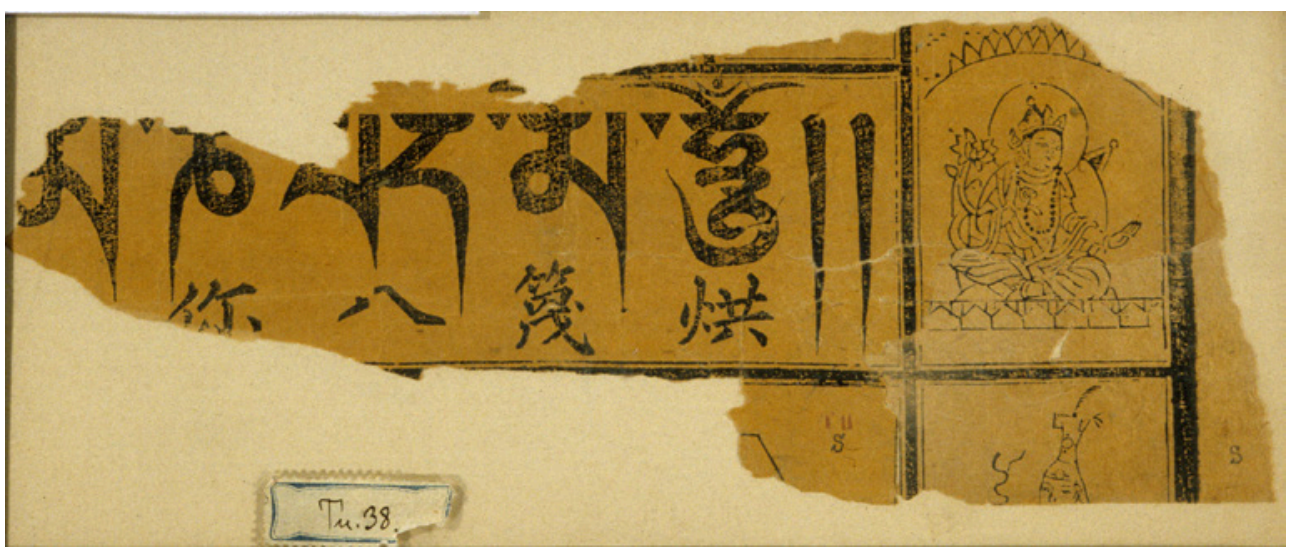

FIGURE 9.7 Paper sheet (TibHT 53).

(C) DEPOSITUM DER BERLIN-BRANDENBURGISCHEN AKADEMIE DER WISSENSCHAFTEN IN DER STAATSBIBLIOTHEK ZU BERLIN - PREUSSISCHER KULTURBESITZ, ORIENTABTEILUNG.

\subsection{Paper Sheet with Six-syllable Mantra and Illustrations}

TibHT 53 is a fragment of what must have been a much larger paper sheet; what remains is only a portion of the right side, with three panels $(24 \times 9.5 \mathrm{~cm})$. The paper is, unlike most of the Tibetan Turfan material, dyed yellow, suggesting that it came from China proper. The largest panel contains the six-syllable mantra of Avalokiteśvara, om maṇi padme hum, in large, fine Tibetan letters, and smaller Chinese characters. To the left of this panel is a small, complete, figure of Avalokiteśvara and below that the head of a donor figure. The distinctive hat of this donor can be used to date the image. It is a close match to a figure found in Bezeklik cave 17, now kept at the Museum for Asiatic Art, Berlin (MIK III 4453). This figure is a female patron from the Mongol period (13th to 14th centuries); thus the prayer sheet probably also dates from this period. It may well have been made in the Yuan capital at Dadu, near present-day Beijing. The original sheet probably featured a larger central image of Avalokiteśvara, which may have been flanked by further donor figures. Given its large size, it could have been displayed in a temple or house.

\subsection{Two Tibetan Pothi Pages}

The Turfan collections contain two fragmentary blockprints. The first, TibHT 69 , is the right side of a pothi style page containing the text of one of the Prajñāpäramitā sūtras (either the version in 8,000 or 25,000 verses). The left margin contains Chinese page numbers (日上三). This feature suggests that 


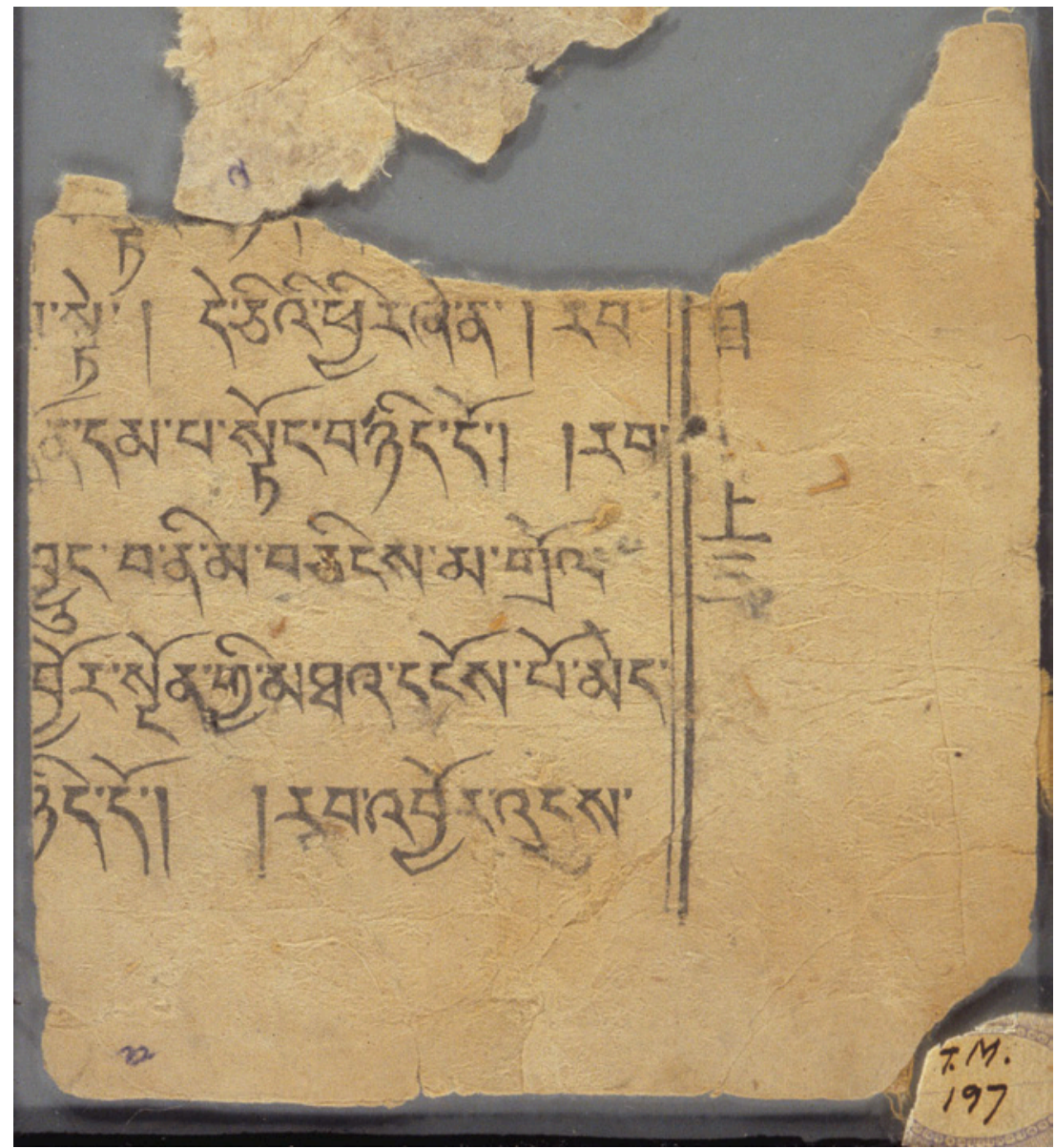

FIGURE 9.8 Fragment of a printed page (TibHT 69).

(C) DEPOSITUM DER BERLIN-BRANDENBURGISCHEN AKADEMIE DER WISSENSCHAFTEN IN DER STAATSBIBLIOTHEK ZU BERLIN - PREUSSISCHER KULTURBESITZ, ORIENTABTEILUNG.

this is a fragment of a book produced in the capital of the Yuan dynasty, often sponsored by queens at the Mongol court. In Tibetan literature these are known as Hor pa ma, 'Mongolian prints' ${ }^{5}$ The Tibetan letters are finely formed, with long tapering descenders, and the margin has two lines, a fine inner and heavy outer line. Many similar printed pages were found by Aurel

15 On the Hor pa ma, see van der Kuijp 1993 and 2010, and Sangpo 2010. 


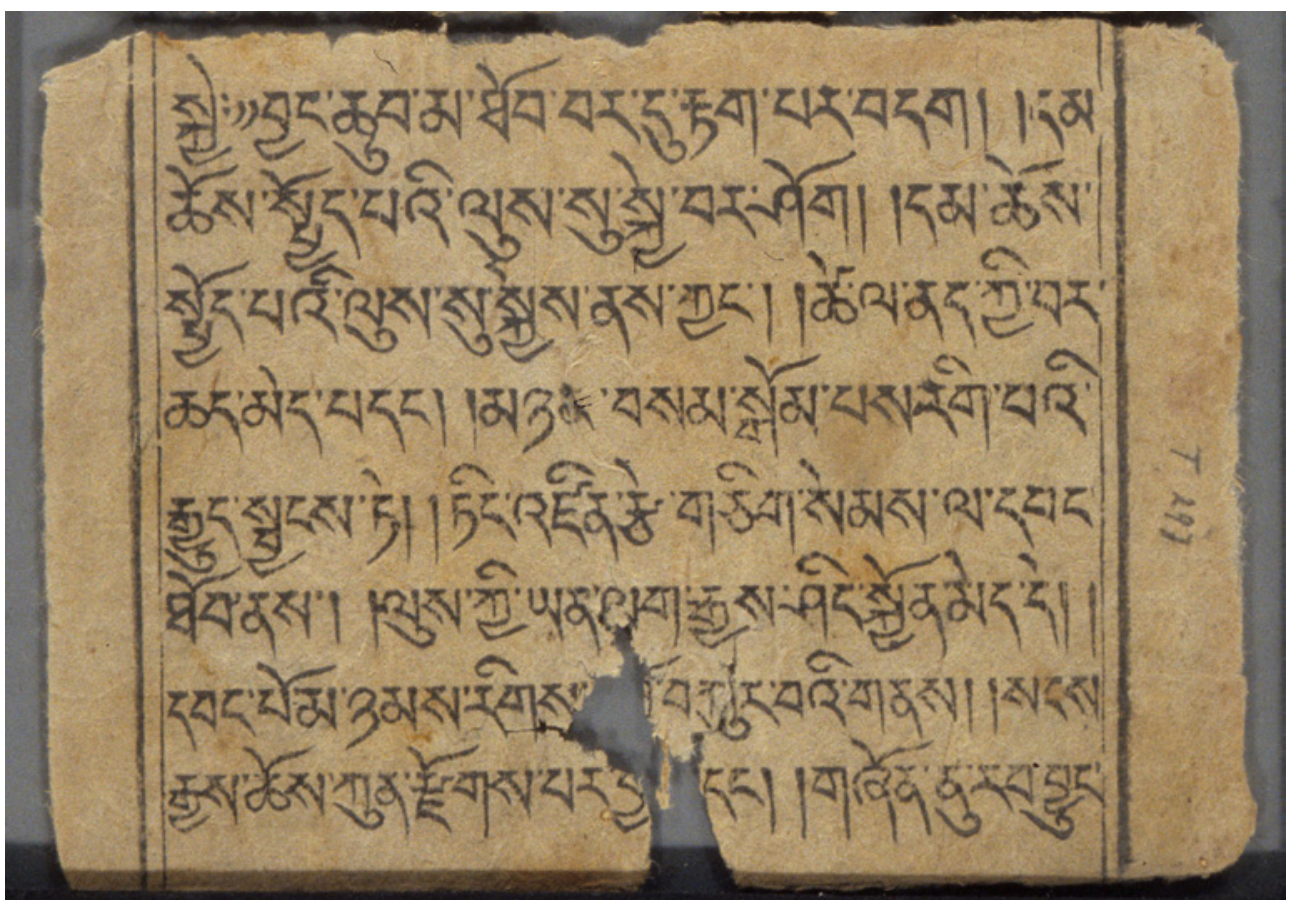

FIGURE 9.9 Pages from a concertina (TibHT 102).

(C) DEPOSITUM DER BERLIN-BRANDENBURGISCHEN AKADEMIE DER WISSENSCHAFTEN IN DER STAATSBIBLIOTHEK ZU BERLIN - PREUSSISCHER KULTURBESITZ, ORIENTABTEILUNG.

Stein at the site of Estin Gol in the Gobi Desert. ${ }^{16}$ The Turfan fragment TibHT 69 has no printed Tibetan on verso, and this blank side has been used to write something in cursive Uighur script, a style which is only found from the 13th century onwards. ${ }^{17}$ The page was probably originally made from two sheets of paper, which have been separated.

The other fragment of a blockprinted page from Turfan, TibHT 119, has only the left margin, containing the Tibetan page numbers ka so bzhi. Thus it is not possible to know whether the original book contained Chinese page numbers in the right margin as well. I have not been able to identify the text. The Tibetan letters of less finely drawn than in TibHT 69, with much shorter descenders, but whether this is due to chronology or differing regional origin between the

16 These are now in the IOL Tib M sequence at the British Library; a catalogue by Tsuguhito Takeuchi and Maho Iuchi is in progress.

17 See the palaeographic scheme in Moriyasu 2004. 
two manuscripts is difficult to say at this stage. There is a chronological clue in the orthography of both manuscripts, which contain no archaic elements, including the ya subscribed to $m a$, which suggests a date towards the end of the Turfan chronology, 13 th or 14 th century.

\subsection{Two Pages of the Ārya-nāgārjuna-praṇidhāna}

These two pages under the single pressmark TibHT 102 are blank on the verso, and may have originally been pasted back to back. At $8 \times 11 \mathrm{~cm}$, they are not of the oblong pothi shape, nor do they seem to have been bound at one side. Thus the form of the original book was probably a concertina. The writing style is somewhere between the two pothi pages discussed above, with long descenders for some letters. The margins have the fine inner and heavy outer line seen in TibHT 69. The writing lacks old orthography, including the ya subscribed to ma. Therefore this fragment probably also dates to the Mongol period, 13th14th centuries. Whether a small textual object like this was made by printing or stamping is difficult to say; both methods would have been feasible. The most obvious issue in the choice between stamping and printing is size. As the size of the wooden block increases, the physical action of stamping becomes more difficult, and less likely to produce an even coverage of ink.

\section{$4 \quad$ Conclusions}

As we have seen, the Tibetan manuscripts from the Turfan collection show the presence of Tibetan writing in the region as far back as the 9th century, in the form of letters received from elsewhere. Later, we have mainly Buddhist manuscripts, suggesting that this was the main function of the Tibetan language and script from the 1oth century onwards. The latest manuscripts are written in styles associated with the Yuan period, so the chronology of the Tibetan manuscripts probably extends through to the middle of the 14th century. This provides a chronological framework for the printed fragments from Turfan.

The majority of this material is not printed in the strict sense of that term, but made with stamps: slips stamped with mantras and small sheets stamped with the ye dharma formula. According to carbon dating carried out on similar sheets in the Otani collection, the ye dharma sheets may date as far back as the 9th-1oth centuries; however given the lack of such material in the Dunhuang collections, and the earliest date of the printed material from Kharakhoto, I would suggest a more conservative dating to the 11th-12th centuries. The relationship between stamping and printing in the early development of the Tibetan print tradition also needs further research. At this stage it seems clear 
in the Tibetan context that stamping and printing were complementary technologies, rather than stages in the development of a single technology. Both techniques were in use in Central Asia before being used for Tibetan, so presumably each was adopted for a specific purpose.

I suggested at the beginning of this paper that the advantage of the fragmentary and accidental nature of what was recovered from Turfan is that it forces us to look beyond texts and colophons to the forms of the artefacts and their original functions. This moves us away from considering manuscripts (and other artefacts) as simply sources of information about the past, towards an attempt to understand their agency in the past. The importance of this move has been eloquently argued in a short book by the archaeologist John Moreland, Archaeology and Text. Moreland argues that while archaeologists might investigate the social functions and agency of objects in the past, they generally exclude texts from their work; while historians, who work with texts, tend to treat them as neutral sources. Moreland writes:

We should focus more than we have done on the fact that documents are not neutral epistles, that they are not disinterested bearers of information about the past. Like other products of human creativity, they were, in fact, active in the production, negotiation and transformation of social relations. $^{18}$

He goes on to suggest how texts ought to be approached:

If we are to fully understand the historical past, we must seek out the details of the way in which people, in historically specific contexts, used, manipulated and confronted both texts and objects. We have to reconstruct the details of their entanglement with words and things, and write the kind of 'thick descriptions' which allow the variety and ingenuity of human creativity, and the difference of the past, to shine through. ${ }^{19}$

One area in which this kind of approach has been tried, with some success, is in the study of the social transformations effected by print technology in Europe, in the work of historians such as Lucien Febvre, Henri-Jean Martin, Elizabeth Eisenstein and Peter Burke. ${ }^{20}$ In these works, printing has been linked to the spread of ideas through greater access to recently composed texts, a development that includes the decline of popular religious beliefs ('superstition') and

\footnotetext{
18 Moreland 2001, 31.

19 Moreland 2001, 97.

$20 \quad$ Key works here are Febvre and Martin 2010, Eisenstein 1982, Burke 1994 (chapter 9).
} 
an increasing political consciousness in popular culture. Printing has also been associated with the accumulation of information leading to a faster development of ideas in science in particular, and, in less positive terms, the standardization of various elements of culture, such as local linguistic differences.

It is debatable whether such changes accompany the development of printing in Asia, which raises the question of how great a part print technology really played in these changes tracked by European historians. However, that is far too large a question to address here. What I want to point out here is that the changes associated with printing in these studies are predicated on the consideration of printed thing as a carrier of texts, rather than as an object with social agency, the kind of object that Moreland writes about. Printed objects used for ritual purposes - such as the indulgences printed by Gutenburg - are not generally part of these classic discussions of the impact of print technology, despite their important social role.

Recently some scholars have attempted to redress this balance; for example in a volume dedicated to Elizabeth Eisenstein's work, Peter Stallybrass has reassessed the cultural importance of printed 'ephemera' such as indulgences and broadsides. And in a rare cross-cultural review of printing in Europe and Asia, Kai-wing Chow has argued that the study of printing in the West should better take into account the co-existence of woodblock printing and moveable type, and the non-linguistic functions of printing allowed by the woodblock print technology. Chow writes: "In brief, it is time to reinvent the narrative of Gutenberg, rescuing the obscured role of woodblock in European printing in the post-Gutenberg period. Resuscitating the importance of woodblock printing in Europe will encourage investigation into the similarities in the history of printing in Europe and Asia." ${ }^{21}$

To return to the Turfan manuscripts, it should be clear from the brief survey I have made here that many of them are closer to Gutenberg's printed indulgences than his Bibles. Investigations of the Hor par ma and other early examples of Tibetan printed books are central to our developing understanding of printing in Tibet, but miscellaneous collections like these from Turfan are also important if we are to understand the broader context of social (and ritual) uses of this technology. Nor are the materials from Turfan peripheral to printing in Tibetan, which emerged in the multicultural, multilingual realm of Eastern Central Asia, informed by Chinese technological developments and given impetus by the interest and support of wealthy Tangut and Mongol patrons. The ways that the technology developed here in the 12th to 14th centuries is surely connected with its later progress in Central Tibet. 


\section{References}

Burke, Peter. 1994. Popular Culture in Early Modern Europe (Revised edition). Aldershot: Scholar Press.

Chow, Kai-wing. 2007. "Reinventing Gutenberg: Woodblock and Movable-Type Printing in Europe and China." In Agent of Change: Print Culture Studies After Elizabeth L. Eisenstein. Ed. S. Alcorn Baron, E. N. Lindquist and E. F. Shevlin. Amherst and Boston: University of Massachusets Press. 169-192.

Dotson, Brandon. 2007. "Divination and Law in the Tibetan Empire: The Role of Dice in the Legislation of Loans, Interest, Marital Law and Troop Conscription." In Contributions to the Cultural History of Early Tibet. Ed. Matthew Kapstein and Brandon Dotson. Leiden: Brill. 3-78.

Drège, Jean-Pierre. 1984. "Les caractères de l'impératrice Wu Zetian dans les manuscrits de Dunhuang et Turfan." Bulletin de l'École française d'Extrême-Orient 73: 339-354.

Eisenstein, Elizabeth. 1982. The Printing Press as an Agent of Change. Cambridge: Cambridge University Press.

Febvre, Lucien and Henri-Jean Martin. 2010. The Coming of the Book: The Impact of Printing, 1450-180o. London: Verso.

Konicki, Peter. 2012. "The Hyakumantō Darani and the Origins of Printing in EighthCentury Japan." International Journal of Asian Studies 9.1: 43-70.

van der Kuijp, Leonard. 1993. "Two Mongol xylographs (Hor Par Ma) of the Tibetan text of Sa skya Pandita's work on Buddhist logic and epistemology." Journal of the International Association of Buddhist Studies 16(2), 279-98.

2010. "Faulty Transmissions: Some Notes on Tibetan Textual Criticism and the Impact of Xylography." In Edition, éditions: l'écrit au Tibet, évolution et devenir. Ed. Anne Chayet, et al. Munich: Indus, 441-464.

Moreland, John. 2001. Archaeology and Text. London: Duckworth.

Moriyasu Takao. 2000. "The Sha-chou Uygurs and the West Uygur Kingdom." Acta Asiatica 78: 28-48.

. 2004. "From Silk, Cotton and Copper Coin to Silver. Transition of the Currency Used by the Uighurs during the period from the 8th to the 14th Centuries." In Turfan Revisited - The First Century of Research into the Arts and Cultures of the Silk Road, edited by Desmond Durkin-Meisterernst et al., 228-239. Berlin: Dietrich Reimer Verlag.

Pan Jixing. 1997. "On the origin of printing in the light of new archaeological discoveries." Chinese Science Bulletin 42.12: 976-981.

Piotrovsky, Mikhail (ed.). 1993. Lost Empire of the Silk Road: Buddhist Art from Khara Khoto (X-XIIIth century). Milan: Electa.

Russell-Smith, Lilla. 2005. Uygur Patronage at Dunhuang. Leiden: Brill. 
Samyosuk, Kira Fyodorovna. 1999. "The Discovery of Khara-khoto." In Lost Empire of the Silk Road. Ed. Mikhail Piotrovsky. Milano: Electra. 31-48.

Sangpo, Sherab. 2010. "Analysis of Tibetan Language Prints Produced During the Yuan Period (hor spar ma)." Inner Asia 15: 201-223.

van Schaik, Sam. 2011. "A New Look at the Origin of the Tibetan Script." In Old Tibetan Documents Monograph Series vol. III. Eds. Yoshiro Imaeda, Matthew Kapstein and Tsuguhito Takeuchi. Tokyo: Tokyo University of Foreign Studies. 45-96.

— 2013. "Dating Early Tibetan Manuscripts: A Paleographical Method." In Scribes, Texts and Rituals in Early Tibet and Dunhuang. Ed. Brandon Dotson, et al. Weisbaden: Reichert Verlag, 119-135.

Shen Weirong. 2010. "Reconstructing the History of Buddhism in Central Eurasia (11th14th Centuries): An Interdisciplinary and Multilingual Approach to the Khara Khoto Texts." In Edition, éditions: l'écrit au Tibet, évolution et devenir. Ed. Anne Chayet, et al. Munich: Indus Verlag, 337-362.

Shi Jinbo. 2005. "Zuizao de zangwen mukeben kaolue (Notes on the Earliest Printed Tibetan Texts by Using the Technology of Wooden Movable Type)". Zhongguo zangxue (China Tibetology) 4: 33-49.

Stallybrass, Peter. 2007. “'Little Jobs': Broadsides and the Printing Revolution.” In Agent of Change: Print Culture Studies After Elizabeth L. Eisenstein. Ed. S. Alcorn Baron, E. N. Lindquist and E. F. Shevlin. Amherst and Boston: University of Massachusetts Press, $315^{-341 .}$

Stoddard, Heather. 2010. "Stitched Books from the Tibetan World." In Edition, éditions: l'écrit au Tibet, évolution et devenir. Ed. Anne Chayet, et al. Munich: Indus Verlag, $363-380$.

Takeuchi, Tsuguhito. 1990. "On the Old Tibetan Texts in the Otani Collection." In Documents et archives provenant de l'Asie centrale. Ed. Association Franco-Japonaise des Études Orientales. Kyoto, Dohosha, 205-216.

-1997-8. Old Tibetan Manuscripts from East Turkestan in The Stein Collection of the British Library. Tokyo/London: Toyo Bunko/British Library.

- 2004. "Sociolinguistic Implications of the use of Tibetan in East Turkestan from the end of Tibetan Domination through the Tangut Period (9th-12th c.)." In Turfan Revisited - The First Century of Research into the Arts and Cultures of the Silk Road. Ed. Desmond Durkin Meisterernst et al. Berlin: Dietrich Reimer Verlag, 341-348.

Taube, Manfred. 1980. Die Tibetica der Berliner Turfansammlung. Berlin: Akademie-Verlag. 